\title{
SPEECH ACTS ON THE POSTERS IN HANDLING REFUGEES IN FREIBURG
}

\author{
Rezki Auliya Handarta \\ Universitas Gadjah Mada, Indonesia
}

\begin{abstract}
The aim of this pragmatic study is to describe the types and the forms of the speech acts on the posters in handling refugees in Freiburg, Germany. This study is a descriptive study that aims to understand the phenomenon of language containing in the use of posters in handling refugees in Freiburg then analyzed and described carefully to make the conclusion.The writer used informants and form of written media namely posters as the source to obtain data. The informants in this study are the staff and the coordinator of the social institutions that handle refugees in Freiburg. The Germany government gives the handling of refugees into social institutions at the local level. They then organize and guide refugees how to live in Germany and in the camps where they live. In Freiburg, social institutions use posters for something important and to guide refugees live or do activities without telling them repeatedly. Posters that they wrote contain much more in the kind of speech acts namely assertive, directive, and phatic. The forms of the speech acts are positive declarative sentences, negative declarative sentences, positive imperative sentences, negative imperative sentences, and positive introgative sentences.
\end{abstract}

Keywords:Pragmatics, Speech Acts, Posters, Refugees

\section{Introduction}

Human and language are two inseparable things. Language is the instrument used to communicate in daily life. According to Chaer and Agustina (2004:11), the main function of language is as the communication or the interaction tool. Through communication act, every speaker intend to deliver the purpose or certain aim towards speaking partner with language as the media. According to Rani (2004:37), there is a speech act in language communication. In a communication, it can be assumed that a speaker articulate the utterance in the aim to inform something towards the speaking partner and expecting the speaking partner (listener/reader) to understand the thing that will be or have been communicated.

Germany's government has recently posted the poster that intended for the refugees that installed in refugees' camp, symbolized by a male picture, crouch under the bath shower with black poop behind him and red-cross line stamped on it (source: okezone.com from WND report, Thursday 21st January 2016). The note under the poster saidplease do not poop in the shower!. What found interesting is in several posters in Germany that intended for the refugees are added with symbolized pictures. According to this circumstance, it can be said that a communication process is already conducted through speech act concept by using words and sentences stamped on that posters. By the existence of these posters, the refugees' management actor in Germany, especially in Freiburg, is able to indirectly giving a message or intention towards the refugees which in this case the refugees' management actor act as the speaker and the refugees act as the posters' readers. This situation is related to the concept expressed by Allan in Lambut (2014:2) regarding the speech act, which explain that the writers or actors that appoint a poster's writer can be assumed as the speaker. Each word printed or wrote on those posters are the utterance that expressed with prosody $\phi$. That written utterance is being read by the readers, as also being heard orally by the listeners. This process occurs in certain context. Aside from that, Wijana (2010: 92) said that speech is every act shape that conducted by the speaker in using their language.

Germany is one of the European countries that declared their willingness in helping the refugees. This willingness is implemented on the policy issued in the middle of September 2015. This policy known as Flüchtlinge Willkommenwhich interpretatively symbolized the country openness towards refugees from the

Corresponding Author: Rezki Auliya Handarta/rezki.handarta@yahoo.com 
countries inflicted in conflict and war like Syria. This issued policy is in line with what expressed by Angela Merkel as the Germany's Chancellor that Germany is the country built in accordance with law and humanity, thus Germany would be more self-open towards refugees issue rather than other European countries. Compared to other European countries, Germany is indeed more responsive and being positive in managing European refugees crisis.In handling refugees, the Germany's government utilized and trusted the process to organizations, local institutions, or church communities to educate, empower, and manage the refugees' potency. They use written media to communicate with refugees in the form of posters. The actor in handling refugeesin Germany especially in Freiburg is using poster for important matters and also to guide them to live their daily life in refugees' camp as well as how to run activities such as using kitchen, bathroom, or public space accordingly to prevent repeated advice by the The actor in handling refugees and made them aware of the rule and being discipline towards it. These posters not only written in Germany language but include translation in English and Arabic. The interesting part is these posters also include picture or illustration because some of the refugees are illiterate and weren't able to fully understand the meaning.

According to the organization that manages the refugees, the poster utilization also found valuable to ease the refugees towards information, because the poster works as media that can be known and seen visually. The Germany's culture also being adamant towards explanation regarding simple matter especially for things related to living in Germany, for example in how to manage the kitchen, they would only explain at one time and reluctant to give another repetition, however, the refugees always come in question whenever they face the situation again. This explanation is acquired by the researcher after conducting the interview with Franz Grasser who is the leader in the social organization of refugees' management (Diakonisker Werk) for refugees' camp in Lorracherstrasse 45, Freiburg. He also explains to the researcher about the reason behind the poster inscribed with don't poop in the shower!and the illustration on the poster that shows someone in a special showerbathroom with poop under him which being " $\mathrm{X}$ " marked on the entire picture. Franz explains that this thing used to happen in the past because the refugees are unfamiliar with the type of bathroom in Germany which totally different with what they have in the past hometown. He also added that although the poster has been posted, this thing keeps happening that made them to continuously redesign the poster with more assertive illustration. This matter not only related to language only but culture as well. He also added that the duty of a translator in his social organization not only to translate the language but to translate culture as well. The translators hired are the immigrants who work in Germany, especially in Freiburg or the students who currently studying in Freiburg and most of them are from Syria. According to Franz, the Syria refugees are easier to communicate due to their ability in speaking English.

Several refugees are still unable to adapt to Germany's culture and conduct full interaction. Some of the informants explain that this condition happened because: 1) they still want to return to their own country, 2) they have severe trauma after long journey, the journey itself not only exhausting but also filled with horrible experience, and 3) they still hold the tradition or religion's aqeedah especially for women in keeping their distance when interacting with others while communication and interaction conducted and experienced by refugees' management actor towards refugees that arrive in Freiburg, Germany has to emerge as the form of responsibility and instinct as social creature. The communication intended to guide the refugees to live and adapt to new environment. The communication process with the refugees begins by introducing Germany culture, especially in Freiburg as well as the language and speech manner used by local people to create mutual understanding.

The authority in handling refugeesin Freiburg is conducting the verbal communication with the refugees in oral and written manner. The verbal communication with oral language is easy to be conducted whenever the refugees are able to speak Germany or English although some refugees are having a limitation in mastering those two languages. However if language barriers occur, the social organization will use translators and in the emergency situation when the translators. Refugees' camp in Bissierstrasse 9 that use refugees' children to communicate because based on their experience, refugees' children only need about three months to learn 
Germany language, thus the authority in handling refugeeswould be focus on teaching the Germany language to refugees' children to ease and bridge the communication with their parents or families.

The refugees in Germany will inevitably have to build communication with Germany citizen especially in the social organization where they being assisted. This matter is difficult and become more complicated due to the women refugees situation that conditioning them to distant themselves that probably influenced by the culture and how to communicate in their origin countries. Regarding this situation, however, they should keep interacting with the organization that responsible to assist them because this condition would help the authority to controls and guides their way of life in Germany especially in Freiburg.

The authority that manages or handlesthe refugees in Freiburg has their own time to interact with the refugees. However, if there are any urgent matters, they all prepared to leave at any moment needed. For the general and technical things, the authority in handling refugees in Freiburg use written media namely posters so it can be seen, remembered and understood by the public, especially the refugees. This research is intended to explain what is the type of the posters in handling refugees in Freiburg and what is the form of speech act expression on the posters in handling refugees in Freiburg. The result of this research is intended to be useful in theoretical, practical and academic aspects.

1. Theoretical value: this research is intended to be useful in developing scientific knowledge of socio and cultural science, especially linguistic science.

2. Practical value: this research is intended to be input for community, philanthropist, and policy maker that work and related to the refugees' management, especially in Indonesia.

3. Academic Value: this research is intended to give contribution through empirical ideas regarding phenomenon and speech act in the communication process and refugees' management which currently become a global issue. In that order, this research is expected to be a reference for other researchers in conducting similar research or another research related to this theme.

\section{Theoretical Framework}

Speech is a word expressed by a speaker to his/her speaking partner when communicating. Speech in the pragmatic study can be understood as the form of speech act itself and as the product of one speech act (Nadar, 2009: 7). Leech (1993:20) expressed a similar opinion that considering speech in pragmatic context as the product of verbal act (not the verbal act itself).According to Wijana (1996: 12), speech used in pragmatic context is a form of speech act. In that case, the speech that being produced is a form of speech act. For example, in the sentence of "Is your hair growing too long?", this sentence can be defined both as a question and imperative sentence. In its relation to pragmatic context, it can be asserted that there is a fundamental difference between sentence and utterance. The sentence is a grammatical entity as the result of linguistic that identified through the user in a certain situation. From the definition above, an utterance can be defined as the speech resulted from speech act which conceives certain meaning/significance and utilized in a certain situation.

Speech act is a linguistic symptom that occurs in the communication process. According to Cunningsworth (via Tarigan, 1990: 41), the speech act theory is the theory that centers it concern on the utilization of language in communicating aim and purpose of the speaker as well as the meaning of the utilized language. Aside from that, Rani (2004: 37) has revealed that in communication, speech act is contained in it, language communication not only a symbol, word, and sentence but would be correctly mentioned as the product or results of manifested symbol or sentence. A speech act is not only a direct representative of the elements meaning. Speech act is the utterance product resulted as part of social interaction (Sumarsono, 2009: 323). Chaer and Agustina (2004: 50) define speech act as the psychological individual symptom determined by the language ability of the speaker in facing certain circumstances. A speech act pressures more in meaning or definition of act in one utterance. In that meaning, it can be understood that speech act used by someone highly determined by several factors, such as language, speak partner, situation and language structure used in that act. Based on the description above, it 
can be concluded that speech act is a social interaction activity conducted by human individual to express the meaning and purpose of language that being used in facing certain circumstances.

According to Wijana (1996: 18), Illocutionary act is an utterance that used to express or inform as well as conducting a particular thing. Illocutionary speech act is the speech act that identified by explicit performative sentence. Illocutionary speech act usually related to granting permission,expressing gratefulness, ordering, offering, and promising (Chaer and Agustina, 2004: 53). Nadar (2009: 14) also expressed a similar opinion that mentions Illocutionary act as the act to be achieved by the speaker in the time of uttering something and could be an act of expressing promise, apologize, threat, forecast, order and etc. In that meaning, it can be said that illocutionary act is not only means to inform but also refers to conduct something. According to Searle (via Tarigan, 1986: 46-48), illocutionary act can be classified into five criteria: a) Assertive: this speech act is involving speaker towards proposition truth that being expressed. For example: declaring/expressing, informing, suggesting, boasting, complaining, demanding, or reporting, b) Directive: this speech act is intended to emerge several effects through listener action, for example: reserving, ordering, begging, asking, suggesting, and advising, c) Commissive: this speech act is involving speaker in the upcoming actions, for example: promising, vowing, offering, and praying, d) Expressive: this speech act has functions to express, reveal, or inform the psychological attitude of the speaker towards an expression of a condition predicted by illocutionary act, for example; expressing gratefulness, congratulate, forgiving, pardoning, praising, expressing condolence, and etc,e) Declarative: the declarative speech act is the condition when the illocutionary performance is successful, will inducing good correspondence between proportionality and reality, for example: surrendering, firing, releasing, baptizing, giving name, isolating, appointing, determining, punishing, convicting, and etc.

The latest perspective regarding speech act from Kreidler (1998:183-194) in his book; Introducing English Semantics, divide speech act into seven categories, which are:1) Assertive Utterances: assertive utterance occurs because the speaker is using language to narrate what they knew and believed, such as expressing, announcing, explaining, showing, mentioning, and reporting., 2) Performative Utterances: performative utterance is the speech act that officially creates or cause what to expressed, for example announcing, baptizing, mentioning, nominating, naming, and sentencing, 3) Verdictive Utterances: verdictive utterance occurs because the speaker is assessing someone else action, usually the speaking partner, for example, accusing, being responsible, and express gratefulness, 4) Expressive Utterances: Expressive utterance occurs because of speaker action, the failure of the speaker and consequences emerged by that failure, for example, confessing, being sympathetic, forgiving, and etc, 5) Directive Utterances: Directive utterance contains the meaning of the speaker in acquiring speaking partner permission to conduct or not conduct an activity. Directive utterance consists of three types, which are commands, request, and suggestions, 6) Commissive Utterances: commissive utterances is the speech act that tied a speaker to conduct an action, for example, agreeing, asking, offering, resisting, promising, and vowing, 7) Phatic Utterances: phatic utterance is one of the speech act that aimed to create a relation between speaker and speaking partner.

\section{Methodology}

This research is descriptive study aimed to understand the linguistic phenomenon which found in the poster in handling refugees in Freiburg, then being analyzed and described diligently to create proper conclusion. This research is using a qualitative type of data. Qualitative data is the data in the form of information, sentence, or words, which in this context is a poster. Qualitative data is used as a foundation to analyze speech act in the posters in handling refugeesin Freiburg, Germany.Data is collected with observation and writing technique. By using writing technique, the researcher will record directly utterances that found in the poster in handling refugeesin Freiburg. Aside from that, phone camera as the supporting tool is needed to acquire data. The phone camera is used to take the pictures of posters in handling refugeesin Freiburg that has been studied and also using interview technique as supporting tool.Identificationand interview method are used to analyze the data. 
Identification method is the method conducted by determining one type of speech act. The speech acts that own similarities in characteristic are classified into one type of speech act, while the speech acts that own different characteristic are classified into the different type of speech act.The interview method is used as in-depth analysis towards discovered data by conducting a direct interview with actor that wrote the posters in handling refugeesin Freiburg as well as interviewing the refugees as the target for those posters. It can be explained as well that in the process of analyzing data, the researcher uses pragmatic analysis in the form of language analysis in the pragmatic perspective (Rustono, 1999:18). This analysis is conducted to determine the speaker intention that either expressed explicitly and/or implicitly behind the sentence used or posters' discourse towards the refugees in Freiburg. The result of data analysis is presented by using general words into written report. The formulation of data analysis result is presented by using general words that usually referred as an informal method. According to Sudaryanto (1993: 145), the informal method is the method that utilized general words in presenting data analysis. Speaking in further, Jati Kesuma (2007: 74), stated that the meaning of the utilization of general words in the presentation of data analysis result are the words that easy to understand while be read.

\section{Kinds of Speech Acts on the Posters in Handling Refugees in Freiburg}

Some of those speech acts are had by the posters in handling refugees in Freiburg and the data are explained as follows:

\section{a) Assertive Act}

Based on Searle (1969), an assertive act is a speech act binding the speakers for the truth on what they say or write. The intention of the speech act expresses the speakers or writers' belief about the matter of the external reality or tells people about something. It means that in this speech act, the speakers or writers try to make sentences, words, or utterances produced in accordance with the facts. The assertive act can be in the form ofthe utterances for expressing, reporting, making a hypothesis, informing,showing, mentioning, concluding, describing, etc.

The assertive acts found in the posters of handling refugees in Freiburg can be seen through the data with their explanations as follows:

1) Cookers are no personal property!

(Poster 1, data $a$ )

Context: The writer announces about the status of the cookers in the kitchen of the refugees' camp.

The utterance of the poster is the assertive acts because it contains the facts about the status of the cookers in the kitchen of the refugees' camp. Delivering the facts on the utterance of the poster is informatively delivered for the readers, especially the refugees staying in the camp and using the kitchen facilities. It is marked by the utterance Cookers are no personal property! (The cookers are not private properties). The utterance refers to delivering facts or information, that is, all cookers in the refugee camp are not personal properties. The statement of the speech is the form of the claim or the act affirming the authority in handling refugees toward something and it must be known by the readers and interlocutors. Therefore, the utterance above is classified as an assertive act.

2) Library opened Monday and Thursday from 5.00 to $6.30 \mathrm{pm}$.

(Poster 6)

Context: The writer of the poster gives information on the operational schedule of the library in the refugee camp.

The speech act of the poster above is an assertive act because it contains the fact or the announcement about the opening hours or the operational time of the library in the refugees' camp. The utterance of the poster is addressed to the readers that want to use the library as a place for reading. The information containing the opening hours of the library also contains a conclusion that besides the informed or printed time on the poster, the library is not operating or closed.Therefore, the informative explanation of the utterance delivered by the writer of the poster is an assertive act. 
3) Are you new in town?

Would you like to get to know people and make contacts?

Would you like to jam with some other musicians?

Do you like homemade food? Do you miss playing football?

Then this platform is for you!

(Poster 10, data $a, b, c, d, e$ and $f$ )

Context: The writer of the poster offers a community or activity that can be followed by the refugees to satisfy their social needs.

The utterances of the poster above use assertive acts because they contain the writer's belief about the condition of the refugees who need a community or a communication space to socializing, doing hobbies, and getting to know each other. The writer's knowledge and conviction about what is needed by the refugees is expressed in the utterances and the writer gives a response in the informative explanation marked by a lingual sign Then this platform is for you! It refers to the information about the community giving services or information to the readers or refugees who are new comers and still need guides about how they live, socialize, and stay in Germany especially in Freiburg. Therefore, the speech acts in the utterances of the poster above are assertive speech acts.

4) Compact guide for refugees and foreigners

How does local transport works?

Where am I allowed to ride my bike?

And who actually has the right of way?

The free app for everyone who wants to get around town safety.

(Poster 12, data $a, b, c, d$, and $e$ )

Context: The writer of the poster gives information to the refugees about the presence of the application that can be used to know transportation systems and ways to mobilize in Freiburg.

The utterances of the poster above show assertive acts because they contain the writer's belief about the reader's need to know the transportation system and mobilization in Germany especially in Freiburg and the fact of the application that can be used to know them. The utterances above are especially addressed to the refugees or the foreigners who newly come in Freiburg. This case is tagged by a lingual marker Compact guide for refugees and foreigners. The informative explanation of the transportation systems and ways how to mobilize in the city safely is delivered by the lingual marker How does local transport works? and The free app for everyone who wants to get around town safety. It refers and brings the readers on the answer or conclusion of the application that can be used to the refugees or foreigners about the transportation and mobilization in Freiburg. Therefore, the utterances of the poster above are categorized as assertive acts.

5) Woman and men are equal and have the same rights. We cannot tolerate violance in any room. Violance against women and children is a crime in Germany!

(Poster 15, data $b, d$, and $f$ )

Context: The refugees handling authority writes the poster dan sticks it in the refugees' camp as the code of conduct and information that must be known together and remembered.

The utterances of the poster above include assertive acts because those contain the writer's belief and conclusion about human rights, especially the status of the equality of rights between men and women in Germany. The speaker also confirms his attitude towards the infraction of the human rights especially in the form of the violence tagged by the lingual marker We cannot tolerate violance in any room. Besides, the poster also contains the informative explanation of the violence on women and children. This action is considered as the criminal action and against the law in Germany, so it contains a conclusion that the refugees doing the action will be processed into the legal recourse. Therefore, the utterances of the poster above show the characteristic of the assertive act.

6) Attention: if you are absent for more than two weeks, you will be deregistered automatically! That means, you will not reserve any money from the office of social affairs, neither do you have heakth insurance! Likewise, the Ministry of Migration and Refugees (BAMF) cannot reach you to carry out the process of asylum. 
(Poster 15, data $n, o$, and $p$ )

Context: The writer delivers the information about the code of conduct or the rule related to the residence status in the refugee camp for the refugees.

The speech act of the poster above is an assertive act because it contains the information addressed to the refugees that stay in the refugee camp. The information is about the absence and staying rules if the refugees want to leave the refugee camp in some time. Besides, the poster includes the information of the residence status if the refugees leave the camp more than the specified time. Therefore, the utterances of the poster above refer to the characteristic of the assertive act.

\section{b) Directive Act}

Searle (via Leech, 1993) states that the directive act is an illocutionary act which have a purpose to produce an effect in the form of the action done by the speaker or the interlocutor. Yule (1996: 93) also says that the directive act is the speech act used by the speaker to order other people to do something. Therefore, it can be concluded that the directive act is a speech act addressed by the speaker to the interlocutor to do something which is desired, expected, or ordered by the speaker. Below here are examples of directive speech acts contained on the posters of handling the refugees in Freiburg and their description as follows:

1) Visitors are allowed to stay maximum three days and you need to apply one week before at the social office. Therefore we need copies of the identity cards of the visitors.

(Poster 2, data $a$ and data $b$ )

Context: The writer (the actor in handling refugees) delivers the information about the staying rule for the visitors in the refugee camp and what must be done about this case.

The utterances of the poster below are directive acts because those contain the writer's wish to be done by the interlocutors or the readers of the poster. The purpose of the utterances states that it is permitted to the visitors to stay or visit maximally for three days and supposed to tell the authorized party one week before. In this case the party is a social organization given an assignment to handle the refugees. The matter is tagged by a lingual marker Visitors are allowed to stay maximum three days and you need to apply one week before at the social office. Besides, the utterance Therefore we need copies of the identity cards of the visitors delivered to the readers of the poster especially the visitors who will visit and stay temporarily in the refugees' camp is about the matters that must be done or the requirement that must be submitted to get a residence permit or visit maximally for three days in the refugees' camp. Therefore, delivering to do something in the utterances is categorized as a directive act.

2) Behaviour in the event of fire. Keep calm. Report the fire. Get to safety. Try to extinguish the fire. (Poster 21)

Context: The writer of the poster orders the readers to do some activities delivered in the utterances of the poster if the fire is happening.

The speech act of the poster above is a directive act because it contains an order about what must be done if the fire is happening, that is, they keep calm, report the fire, haste to find a safe place, or try to extinguish the fire. The directive marker of the utterances is tagged by the imperative words Keep, Report, Get to, and Try. Therefore, the speaker hopes the readers to do activities delivered through the poster if the fire is happening. Therefore, the command delivered by the speaker or writer shows the characteristic of the directive act.

3) The kitchen should not be used until further notice, due to mold.

(Poster 22)

Context: On one of the refugee camp building floors, there is a kitchen that is banned to be used because it will be sterilized and cleaned.

The speech act of the poster is a directive act because the writer of the poster wants the refugees not to use the kitchen provisionally due to mold and it will be be sterilized and cleaned. The directive marker in the sentence above is the imperative words "should not be used". Besides, there is a lingual negation marker, so the utterance 
contains a prohibition or a command not to do what the writer prohibits, that is, the refugees are banned to use the kitchen provisionally. Therefore, it can be concluded that the speech act of the poster is a directive act.

4) The green bin is for: Newspaper, magazines, paper bags, cardboards boxes (cut up). The brown bin is for: Fruit and vegetables waste, leftover food, flowers, plants. The yellow bin is for: Tins, cans, empty aerosols, drink cartons, plastic packaging. The black bin is for: Nappies, sweepings, hygiene products, textiles, rubber and plastic parts, ashes.

(Poster 13, data $a, b, c$, and $d$ )

Context: The writer of the poster informs about what the types of waste that can be inserted or thrown into the bins that has been separated by colours.

The speech act of the poster above is a directive act because it contains the speaker's aim to the interlocutors so that they throws the waste in accordance with the information of the colour classification of the bins based on the types of waste that can be inserted into the bins. The utterances of the poster are addressed to the readers especially the refugees in the refugees' camp so that they apply discipline in sanitation cases. The writer gives the information of bin colours and types of waste that can be thrown into the bins so that the readers do something that is delivered and based on the information of the utterances in the poster, that is, they should throw the waste based on the colours and types of waste which have been attached. Therefore, the utterances of the poster are categorized as directive acts.

5) Please do not poop in the shower!

(Poster 23)

Context: The writer forbids the refugeesto poopin the shower ofthe refugee camp because it is onlyused totake a bath.

The speech actinthe sentence of the poster aboveis a directiveact because in this situation, the writer who is the authority in handling refugeeasksthe refugees not to usethe showerto poop. In the Germany culture, the shower and toilet to defecating has been separated. Therefore, the prohibition of defecating in the showersalso becomes a commandto defecate in the toiletthat has been provided. The directive actin the utterance of the posteris taggedbythe use of the imperative words "Do not". The wordsrefer toa prohibition to defecate or poop in the shower. Therefore, the utterance of the posteris a directive act.

6) Obligation to stay in the place of residence: if you live here, you have to sleep here. If you want to be absent for a longer period of time, please apply to the facility managers.

(Poster 15, data land data $m$ )

Context: The writer of the poster conveys the code of the conduct in staying in the refugees' camp.

The utterances of the poster aboveare directive acts becausethose containa commandto the interlocutorsto do something. The speaker wants to the readers or the refugees to obey the rulesrelated totheir residence,that is, if they are registered ascertaincamp residents, they must stay in the camp. If they want to leave the campthat is their residence temporarily, they immediately have to reportor ask permission to the facility managers in the refugees' camp. Therefore, the utterances above which illustrate the speaker's willto be doneby the interlocutors refer tothe directive acts.

7) Come over! Let's plant and garden together!

(Poster 25, data $c$ and data $e$ )

Context: The writer of the poster invites the refugees to do outdoor activities with gardening in an area together.

The utterances in the poster are the directive acts because those contain an invitation to do the following activities: gardening and planting trees together. The imperative words Let's plant show a directive act. Besides, the beginning of the discourse is also started by the imperative utterance Come over! It can be concluded that the writer invites the readers of the poster to do some activities. The activities are planting trees and gardening together. Therefore, the utterances in the poster are directive acts.

8) Visitors have to register with CDS Security!

(Poster 26) 
Context: In front of the gates of the refugee camp, there is a poster addressed to visitors, families, friends, and the refugees' relation who occupy the refugees' camp to report themselves in order to get admission into the refugees' camp.

The utterance of the poster is a directive act because it is addressed to the visitors or the refugees' relation who want to enter the refugees' camp to report to the camp security so that they are given admission and registered as visitors. The authority in handling refugees will give ID Card especially if the visitors area permitted to enter with some requirements. The lingual marker showing that the utterance of the poster is a directive act is in the words have to. The lingual marker refers to the writer's will to the readers of the poster to do something obliged. In this case, the utterance is addressed to the visitors who will enter into the refugees' camp either non refugees, refugees' relation in the camp, or the refugees who are not registered to stay in the camp. Therefore, the utterance in the poster is a directive act.

9) Please don't litter! Trash is only to be thrown in the trash can. Bulk trash as e.g furniture should be thrown in the big barrels! Shopping carts must not be brought onto the compound, they belong to the supermarket.

(Poster 15, data $h, i, j$, and $k$ )

Context: The writer of the poster conveys the code of the conduct about the waste in the refugees' camp.

The utterances of the poster above are the directive acts because those contain a command not to do something or a prohibition, that is, the readers is forbidden to throw the rubbish carelessly or litter the environment. The prohibition is shown by a lingual marker Please don't litter! And also the command to do something is shown by a lingual marker Bulk trash as e.g furniture should be thrown in the big barrels! It is the objectification of the writer's will so that the readers or the refugees do what is delivered through the utterances. Therefore, the purpose addressed to the readers through the poster above shows the characteristic of the directive act.

\section{c) Phatic Act}

Kreidler (1998) in his book Introducing English Semantics states that a phatic is the speech act having a purpose to create a relationship between the speaker and dan the interlocutor. According to Wijaya (2010), a phatic act is a speech act which is used by the speaker to make a contact with other people and has the essential meaning to hold or establish a relationship between the speaker and the interlocutor. Below here are examples of the phatic acts found in this study and their explanations as follow:

10) We warmly welcome you here at the Bissierstraße, no matter which color of skin, culture, nationality, religion or gender you have!

(Poster 28)

Context: The writer of the poster expresses his view on the refugees and posts it on the bulletin board in the refugee camp.

The utterance of the poster above is included in the phatic act because it contains an attitude statement toward the refugees who are being or will live in the Bissierstraße refugee camp. The statement has a purpose to create a good relationship between the writer or speaker, who are the actors in handling refugees, with the readers or interlocutors, who are the refugees. It also has a purpose to create a good relationship among the fellow readers or interlocutors. Therefore, it can be concluded that the writer of the poster expresses the utterance by using the phatic act.

11) We are looking forward to all who come.

(Poster 19, data $j$ )

Context: The writer of the poster closes a discourse in the poster with the utterance that inspires and tries to attract the reader's sympathy in order to participate in the event which will be followed by the writer or the authority in handling refugees.

The utterance of the poster above is categorized as a phatic act because it includes delivering an attitude and created relationships to the readers who will participate in the activity held by the writer. This case has a 
purpose to create a good relationship between the writer of the poster and the readers. Therefore, the utterance shows the characteristic of the phatic act.

12) We are looking forward to spending time with you!

(Poster 25, data $d$ )

Context: The writer of the poster conveys the utterance that describes the evocative elements and emotional closeness of the activity that will be done. The activity is gardening with people from different cultural backgrounds and different countries.

The utterance above is a phatic act because it is expressed to create a relationship and appeal the sensation of the emotional closeness to the readers. This case can represent the situation happened if the readers participate in this gardening activity held by the writer of the poster. Therefore, it can be concluded that the utterance above is delivered to create a relationship between the speaker and the interlocutor. The elements creating the relationship show the characteristic of the phatic act.

\section{Forms Of Speech Acts On The Posters In Handling Refugees In Freiburg}

The forms of speech acts on the posters in handling refugees in Freiburg are explained using mood of sentences. The following forms of speech acts on the posters in handling refugees are described below.

\section{a) Positive Declarative Sentence}

According to Wijana (2009), declarative sentence is a sentence that is conventionally used to inform about something. Forms of declarative sentences on posters in handling refugees in Freiburg contain more information or announcements addressed to the refugees because it has become the main task of the poster's writer in this case the authority of handling refugees in guiding and providing services to the refugees as the commitment of Germany in general which has declared its openness to refugees. Kridalaksana (1993) explains that declarative sentences are generally to state or tell something. In written form, it is marked with (.) or nothing on the end of a sentence. Below are examples of speech acts on the posters in handling refugees in Freiburg shaped declarative sentences and an explanation.

1) Counselling for pregnant women and mothers with children up to three years. (Poster 5)

Context: Writer of the poster informs about counseling services for pregnant women and mothers with children under three years.

Assertive speech act above has a declarative tone so that the intonation or sentence written form is positive declarative sentence because it contains no negation marker in it. Assertive speech act which is formed is positive declarative sentence. It has informative aspect regarding the counseling services given to women who are pregnant and mothers who have children under three years in the camp of refugees. It is also informed that those who are not included or mentioned in the poster cannot get counseling.

2) DRK-Sosialdienst closed from 12.30 till 13.30.

(Poster 11)

Context: Writer of the poster conveys information regarding office hours rest or services of the organization which has the authority in handling refugees.

Assertive speech act on the poster above has the form of a positive declarative sentence because it contains no negation marker. The declarative sentence contains facts about break time of the social organization that has a duty in handling refugees. Besides, this poster also gives an informative description that the time on the poster from 12:30 till 13:30, the authority of the handling refugees is closed or not operating.

\section{b) Negative Declarative Sentence}


Here are examples of negative declarative sentences marked by the negation lingual marker or negation element in it.

3) When you knock and I don't react, this simply means I am busy. Secondly, I don't give people houses or apartments, I am not the right person to talk to.

(Poster 8, data $c$ dan $e$ )

Context: Writer of the poster tells the readers especially refugees about the status of the writer in the camp of refugees.

Assertive speech acts above which are formed are declarative sentences. Declarative sentences which are formed are negative declarative sentences because they contain elements of negation in them. The negation markers are marked with a marker lingual don't on the data $c$ and $e$ and am not in the data $e$. The utterances above contain information, beliefs, and explanation of the writer on the status of work in the camp of refugees. The utterances on the poster above are aimed to the readers that the refugees who stay in the camp of refugees where the writer works. Informative utterances above show the writer intends to convey something that previously most of the readers in this case the refugees do not know.

4) We cannot tolerate violance in any room.

(Poster 15, data $d$ )

Context: The authority in handling refugees wrote a poster and put it in the camp of refugees as rules and information that should be known, shared and remembered.

Assertive speech act above is formed as negative declarative sentence because there is a negation element in it. Lingual marker cannot is a form consisting of modal can and negation not. The utterance contains affirmation of the writer towards human rights violations especially in the form of violence.

\section{c) Positive Imperative Sentence}

According to Wijana (2009), the imperative sentence is the sentence which is used to express a command, invitation, request, or ordering. Kridalaksana (1993) explains that sentennce which has imperative intonation in general is a sentence that contains the meaning of command or prohibition, in written form marked with (.) Or (!). On the posters in handling refugees in Freiburg, imperative sentences nearly all are used and addressed to the refugees because the authority are guiding refugees how to live and move well in the camp of refugees and in the neighborhood especially in Freiburg. Below are examples of speech acts on posters in handling refugees in Freiburg which are formed as positive imperative sentences because there is no negation marker in them.

5) Join us at the Refugee Women's Cafe and let us make plans together.

(Poster 20)

Context: The authority in handling refugees made activitiy in the field of art specifically for the women refugees.

Directive speech act on the poster above has intonation as imperative that the sentence is positive imperative sentence. Positive imperative intonation is marked by the absence of negation lingual marker and there are command words in it such as Join us and let us. The imperative sentence above is aimed to invite the refugees especially women to participate in activity related to the arts and a meeting to plan and discuss the activities or works to be made regarding with arts.

6) Smoking is prohibited in all rooms!

(Poster 27, data $a$ )

Context: Writer of poster writes a ban on smoking in all indoor refugees' camp as a discipline rule which must be obeyed.

Directive speech act on the poster above has the imperative intonation. Sentence which is formed is positive imperative sentence because it does not contain element of negation. Marker lingual is prohibited, which means "forbidden" in the poster sentence refers to the desire of the writer to the readers of the poster for not doing smoking in all rooms in the refugees' camp without exception.

\section{d) Negative Imperative Sentence}


Below are examples of speech acts on the posters in handling refugees in Freiburg which have the forms of negative imperative sentences.

7) Please do not disturb anyone's sleep.

(Poster 15, data $g$ )

Context: The writer of poster tells the readers of poster to pay attention about the rule regarding hours or time of sleep and a ban on making a nuisance on the rest time in refugees' camp.

Directive speech act on the poster above has a form of negative imperative sentence. Imperative intonation and lingual marker do not disturb is a marker of negative imperative sentence on the poster because there is a negative marker in it to show the utterance as a ban. Negative imperative sentence is formed containing the intent to prohibit the camp's residents to not create a disturbance at the rest time that has been set. The poster is also intended to make the refugees using the effective time specified in the utterance to take a rest and not use it for other things that can interfere with the comfort and good environment for residents themselves, other residents, as well as the refugees' camp itself.

8) The kitchen should not be used until further notice, due to mold.

(Poster 22)

Context: In one of refugees' camp especially in one building floor there is a kitchen that is banned to be used because it would be sterilized and cleaned.

Directive speech act above has imperative tone marked with the word should with negation not. Therefore, the form is negative imperative sentence. The sentence indicates a prohibition. Writer in the poster wants the refugees to not use the kitchen for a while due to mold and to be cleaned or sterilized.

\section{e) Positive Introgative Sentence}

Wijana (2009) revealed that introgatif sentence is a sentence that is used to ask something. Introgative sentence in written form marked with (?) (Kridalaksana, 1993). On posters in handling refugees in Freiburg, introgative sentences which are formed do not really ask something and expect answers from readers but bring the readers to the conclusion, belief, or the fact that the speaker or writer wants to be informed through the posters. The following examples introgative sentences on the posters in handling refugees in Freiburg and its description:

9) Looking for work?

(Poster 4)

Context: The actor in handling refugees tells about job vacancy that can be proposed or is required by refugees.

Assertive speech act above has a form of introgative sentence. Sentence which is formed above is positive introgative sentence because it does not have negation marker in it. The utterance above can be answered with yes / no. However, the intention of the question is not merely asking if the readers in this case refugees looking for job because the writer's purpose in this case the actor in handling refugees in Freiburg provides information on job vacancy that can be proposed by refugees while being refugees in Freiburg, Germany.

10) Do you know someone who would like to learn write and read in Germany?

(Poster 3, data $a$ )

Context: Writer of poster conveys information about the Germany language course which can be followed by the refugees.

Directive speech act on the poster above has the form of introgative sentence. Introgative sentence which is formed is positive introgative sentence because it does not have negation marker in it. The utterance ask question about people who want or need to learn Germany languange. Positive introgative sentence on the poster above is actually intended to invite the readers of poster which is marked by the next sentence (On Thursday 10-12 am Karilina Kurkowska (Karo) is at Bissierstraße 9 for all questions concerning German classes, poster 3 data $b$ ) containing invitatin to join and learn Germany language that can be followed by the refugees to write and read in Germany language.

\section{Conclusion}


Many of the refugees are still not able to adapt to Germany's culture. Moreover, they do not quickly blend and cover themselves with the surrounding community association especially with the Germany people in Freiburg. It happens because:1) they still want to return to their country,2) deep trauma after a long journey and a trip which was not only exhausting but also full of bad experiences.3) they still hold strong traditions or religious belief especially in women who maintain a distance in interaction.In facing the barriers in communcation with the refugees, the actors in social institutions do: a)the use of translators, b) the use of Google translate, c)the use of refugees' children.

In handling refugees, the actors in social organizations also use the written media in communicating with refugees that is poster. The use it for something important and to guide the way the refugees live or do activities such as using a kitchen, bathroom, or other public facilities without telling them repeatedly and made them always see it and run disciplines. The posters contain much more in the types of speech acts namely assertive, directive, and phatic. The forms of speech acts which are formed in the posters in handling refugees in Freiburg arepositive declarative sentences, negative declarative sentences, positive imperative sentences, negative imperative sentences, and positive introgative sentences.

\section{References:}

Chaer, Abdul and Leonie Agustina, 1995, Sosiolinguistik: Perkenalan Awal (Jakarta: Rineka Cipta).

Coumming, Louise, 1999,Pragmatics, A Mutidiciplinary Perspective(New York: Oxford UniversityPress).

Djajasudarma, T. Fatimah, 1993,Metode Linguistik: Ancangan Metode Penelitian dan Kajian. (Bandung: PT Eresco).

Jati Kesuma, Tri Mastoyo, 2007,Pengantar (Metode) penelitian Bahasa(Yogyakarta: Carasvatibooks).

Kreidler, Charles W, 1998, Intrducing English Semantics, (New York: Routledge).

Lambut, Fransiscus K, 2014,Tindak Tutur Ilokusi dalam Papan Peringatan pada Sarana Publik di Kota Melbourne (Yogyakarta: UGM).

Leech, Geoffrey, 1982,The Principles of Pragmatics, Translated. Oka, M.D.D. and Setyadi Setyapranata, 1993,Prinsip-Prinsip Pragmatik (Jakarta: Universitas Indonesia Press).

Mulyana, 2005,Kajian Wacana (Yogyakarta: Tiara Wacana).

Nababan, P.W.J, 1987,Ilmu Pragmatik: Teori dan Penerapannya(Jakarta: Dikti).

Nadar, F.X, 2009,Pragmatik dan Penelitian Pragmatik(Yogyakarta: Graha Ilmu).

Rani, Abdul, 2004,Analisis Wacana: Sebuah Kajian Bahasa dalam Pemakaian(Malang: Bayumedia Publishing).

Rohmadi. Muhammad, 2004,Pragmatik: Teori dan Analisis(Yogyakarta: Lingkar Media).

Rustono, 1999,Pokok-Pokok Pragmatik(Semarang: Ikip Semarang Press).

Searle, J.R, 1969, Speech acts: An Essay in the Philosophy of Language(Cambridge: Cambridge University Press).

Sudaryanto, 1993, Metode dan Aneka Teknik Analisis Bahasa(Yogyakarta: Duta Wacana University Press).

Sumarsono, 2009,Sosiolinguistik(Yogyakarta. Pustaka Pelajar)

Tarigan, Henry Guntur, 1986, Pengajaran Pragmatik(Bandung: Angkasa).

Wijana, I Dewa Putu, 1996,Dasar-dasar Pragmatik(Yogyakarta: Andi Offset).

Yule, George, 1996,Pragmatics, New York: Oxford University Press, Translated. Indah Fajar Wahyuni, 2006,Pragmatik(Yogyakarta: Pustaka Pelajar). 